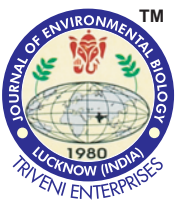

\title{
Seasonal changes of zooplankton community around Dokdo in the East Sea
}

\section{Authors Info \\ D.K. Pardianto ${ }^{1}$, B.R. Lee ${ }^{1}$, K.H. Choi $^{2}$ and W. Park ${ }^{1 *}$ \\ 1 Department of Marine Biology, Pukyong National University, Busan-48513, Korea \\ ${ }^{2}$ Dokdo Fisheries Research Center, National Institute of Fisheries Science, Pohang-37709, Korea}

*Corresponding Author Email : wpark@pknu.ac.kr

\section{Edited by}

Professor Chae Woo Ma

\section{Reviewed by}

Professor Jung Hwa Choi

Professor Sang H. Lee

\section{Abstract}

Aim: The aim of this study was to investigate the seasonal changes in distribution, composition and abundance of zooplankton community in relation with hydrography such as temperature and salinity in the East Sea.

Methodology: Seasonal changes of zooplankton community were studied at 12 stations near Dokdo in the East Sea. Zooplankton were seasonally sampled in 2011. Water temperature and salinity were simultaneously measured at the zooplankton sampling sites.

Results: The mean surface water temperature was highest in summer, lowest in winter and intermediate in spring and fall. The mean surface water salinity was highest in winter and spring, lowest in summer and intermediate in fall. Total 215 species belonging to 65 families were identified. Zooplankton mean densities gradually increased from winter to fall. Total species number was lowest in winter and highest in summer. Copepods prevailed as dominant zooplankton groups in all seasons. The mean densities of dominant zooplankton species varied with seasons.

Interpretation: Zooplankton communities varied with season, particularly water masses were driven by water currents as a main factor controlling zooplankton community composition, abundance and distribution.

Key words: Dokdo, Hydrography, Seasonal changes, Zooplankton

\begin{tabular}{|c|c|c|c|}
\hline $\begin{array}{l}\text { Oceanography } \\
\text { characteristics }\end{array}$ & Temperature & Salinity & \\
\hline $\begin{array}{l}\text { - Temperature } \\
\text { (seasonally) } \\
\text { - Salinity (season } \\
\text { ally) }\end{array}$ & $\begin{array}{l}\text { - Summer (highest) } \\
\text { - Winter (lowest) }\end{array}$ & $\begin{array}{l}\text { - Winter/spring (hig } \\
\text { hest) } \\
\text { - Summer (lowest) }\end{array}$ & \\
\hline Zooplankton & \multicolumn{2}{|c|}{ Zooplankton commurity } & \\
\hline $\begin{array}{l}\text { - } 12 \text { stations near } \\
\text { Dokdo Islets } \\
\text { - Seasonally } \\
\text { - Distribution } \\
\text { composition } \\
\text { abundanœ }\end{array}$ & \multicolumn{2}{|c|}{$\begin{array}{l}\text { - Mean densities gradually increased fromw } \\
\text { inter to fall. } \\
\text { - Total species number was lowest in winter } \\
\text { and highest in summer. } \\
\text { - Mean densities of dominant zooplankton } \\
\text { species varied with seasons. }\end{array}$} & $\begin{array}{l}\text { Zooplankton corrmunities varied } \\
\text { with season and particularly water } \\
\text { masses, driven by water currents } \\
\text { as a main factor controlling zoopl } \\
\text { ankton community composition, a } \\
\text { bundance and distribution. }\end{array}$ \\
\hline
\end{tabular}

How to cite : Pardianto, D.K., B.R. Lee, K.H. Choi and W. Park: Seasonal changes of zooplankton community around Dokdo in the East Sea. J. Environ. Biol, 40, 884-895 (2019). DOI: http://doi.org/10.22438/jeb/40/5(SI)/SI-09 


\section{Introduction}

The East Sea is located at the northeastern Asian continent and the west of Pacific Ocean. It is well known as a semi-enclosed marginal sea (Chough et al., 2000). The sea is divided into two parts, northern and southern (Chough et al., 2000; Talley et al., 2006). The northern part of East Sea is characterized by cold water, originating from North Korea Cold Current (NKCC), a branch of Liman Current (Cough et al., 2000; Talleyet al., 2006). The southern part of sea is characterized by warm water, influenced by East Korea Warm Current (EKWC), a branch of Tsushima Warm Current (Chang et al., 2002; Ashjian et al., 2005; Kim et al., 2016).

Dokdo is centrally located in the southern East Sea/Japan Sea. The hydrography around this island is influenced mainly by three water masses the East Sea Intermediate Water (ESIW), the East Sea Proper Water (ESPW) and the Tsushima Warm Current (TWC) (Chang et al., 2002). ESIW and ESPW are characterized by cold $\left(1-5^{\circ} \mathrm{C}\right)$ and less saline water (<34.00 psu) (Park et al., 2016a). TWC is characterized by more saline $(>34.00$ psu) and warm water $\left(>15^{\circ} \mathrm{C}\right.$ ) (Chang et al., 2004; Kim et al., 2004).

Seasonal changes of hydrographic conditions such as water currents, temperature and salinity influence the distribution and structure community of zooplankton around Dokdo (Hirakawa et al., 1995; Park and Choi, 1997; Chiba and Saino, 2003; Ashjian et al., 2005; Park et al., 2016a). Distribution of planktonic organisms, particularly zooplankton are determined largely by water currents (Pinca and Dallot, 1997; Iguchi, 2004;
Pepin et al., 2011). Water currents bringing either warm- or coldwater affect zooplankton composition and abundance in the East Sea because each species of zooplankton has a preferable range of water temperature (Park et al., 1991; Krause et al., 1995).

Water salinity along with water temperature determines the distribution of living organisms. Water salinity varies gradually over weeks or months due to seasonal precipitation or evaporation (Johnson and Allen, 2012; Richardson, 2008; Varadharajan and Soundarapandian, 2013). Changes in salinity determine the distribution and composition of zooplankton community because each species has a different ability to tolerate water salinity changes (Mauchline, 1998). Some zooplankton species such as Acartia tonsa and Centropages hamatus are less tolerant towards changing salinity (Lance, 1963; 1964). Meanwhile, Acartia longiremis and Pseudocalanus sp. have wide range of salinity levels (Rochet and Grainger, 1988).

The present study was carried out to investigate the seasonal changes in distribution, composition and abundance of zooplankton community in relation with hydrographies of the East Sea.

\section{Materials and Methods}

The East Sea is located in the vicinity of Dokdo $\left(37^{\circ} 00^{\prime}\right.$ $37^{\circ} 30^{\prime} \mathrm{N}$ to $\left.131^{\circ} 30^{\prime}-132^{\circ} 10^{\prime} \mathrm{E}\right)$ (Fig. 1). Zooplankton were collected during winter (February-March), spring (May), summer (August-September) and fall (November) in 2011.

Zooplanktons were collected with a Bongo net of diameter $60 \mathrm{~cm}$ and mesh size $330 \mu \mathrm{m}$, equipped with a flow

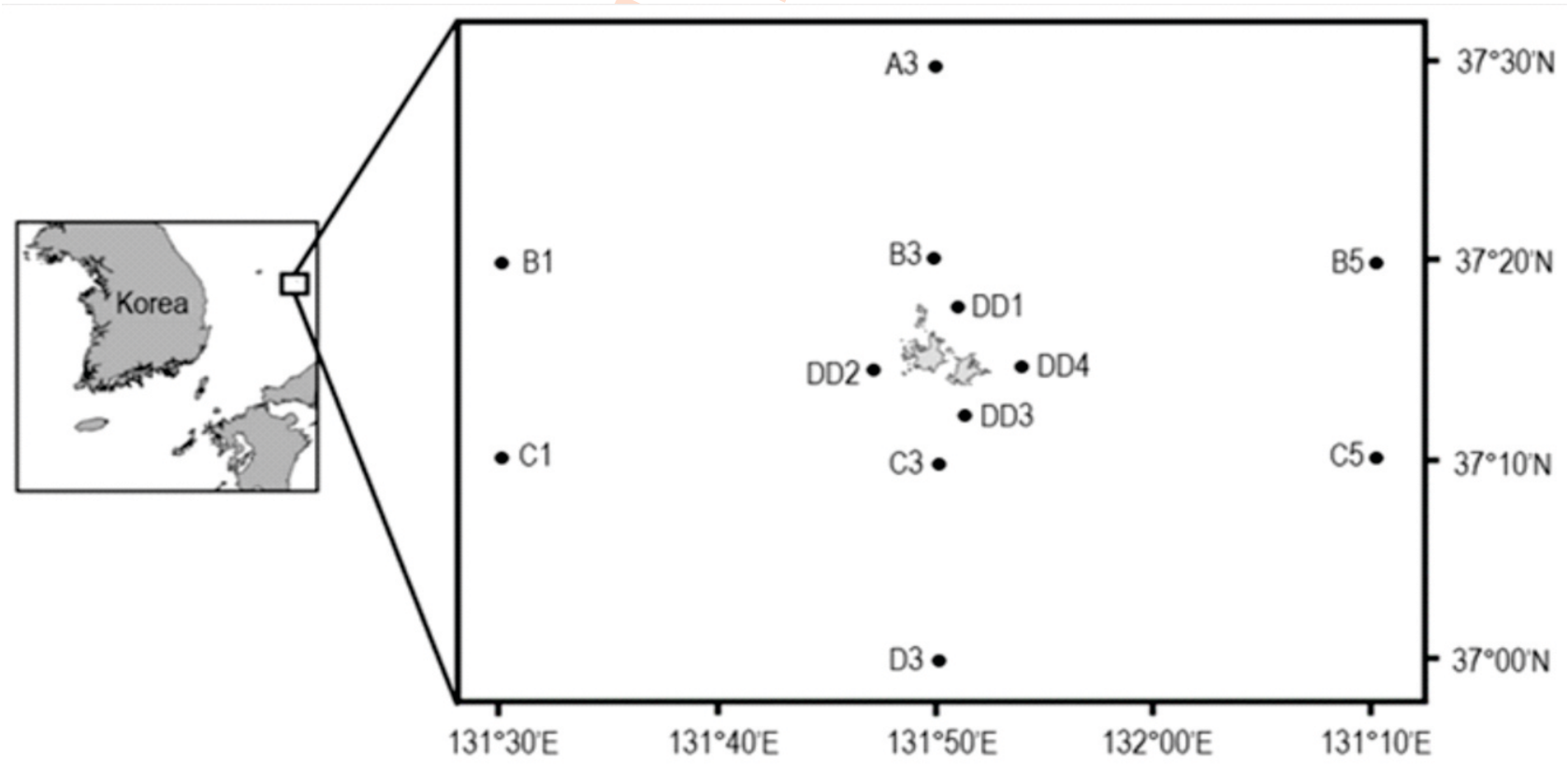

Fig. 1 : Location of sampling stations around Dokdo in the East Sea. 
meter at the mouth of the net to determine volume of water passing through the net during sampling. A Bongo net was double-obliquely towed from approximate up to $200 \mathrm{~m}$ depth (or from maximum depth if the bottom depth was shallower than 200 $\mathrm{m})$ to surface layer. Temperature and salinity were simultaneously recorded during zooplankton sampling with CTD (SeaBird Co.).Seasonal vertical characteristics of water temperature and salinity at all stations around Dokdo were profiled at 1, 10 and 50 mdepth.

After sampling zooplankton, samples were preserved in $70 \%$ ethanol immediately for enumeration and species identification. In laboratory, zooplankton biomass was determined by displacement volume method then, samples were sequentially split using a plankton splitter into final aliquots or subsamples containing about 300-500 specimens. Zooplankton samples were identified to species level, if possible, under a dissecting microscope using Bogorov Counting Tray.

Seasonal variation of zooplankton community was analyzed for Species richness (d), Shannon Diversity Index $(H)$ and Evenness index $\left(\mathrm{J}^{\prime}\right)$. Cluster analysis and non-metric multidimensional scaling (nMDS) were computed using BrayCurtis similarity index to examine similarity among seasons. nMDS ordination having a stress value $<0.05$ means excellent to interpreting data; $<0.1$ means good to interpreting data; $<0.2$ means data useable for interpreting data. And $>0.2$ means could be challenging to interpreting data (Clarke, 1993).

Data of species abundance were transformed by logtransformed $(\log (x+1))$ to reduce bias due to extremely abundance species (Field et al.,1982; Legendre and Legendre, 1998). Differences of zooplankton community between groups (seasons) were tested with one-way analysis of similarity (Oneway ANOSIM) and similarity percentages (SIMPER). When $p$ value $<0.1 \%$ and $R$-value were close to one, it was represented as significant differences between groups (Clarke and Warwick, 2001).

\section{Results and Discussion}

Seasonal vertical profile of temperature and salinity at all stations around Dokdo indicated seasonal variation at each depth layer (Fig. 2, 3). During winter, water temperature was lowest and ranged from 8.70 to $11.18^{\circ} \mathrm{C}$ at three depth layers. Water temperature was highest during summer, ranging from 23.0 to $26.1^{\circ} \mathrm{C}$ at 1 and $10 \mathrm{~m}$ depth and 7.9 to $14.4^{\circ} \mathrm{C}$ at $50 \mathrm{~m}$ depth. During spring and fall, water temperatures ranged from 16.17 to $18.91^{\circ} \mathrm{C}$ at 1 and $10 \mathrm{~m}$ depth, while water temperature at $50 \mathrm{~m}$ depth ranged from 11.14 to $14.44^{\circ} \mathrm{C}$ during spring and 14.29 to $18.56^{\circ} \mathrm{C}$ during fall. Water temperature at ca. $200 \mathrm{~m}$ were similar at all stations and season, indicating $\sim 1^{\circ} \mathrm{C}$.

The horizontal distribution pattern of water salinity at all depth layers varied with season (Fig. 4). The mean water salinities were highest in winter and spring, ranging from 33.5 to $34.9 \mathrm{psu}$ at three-depth layers. The mean water salinities were lowest in summer. In particular, water salinities at 1 and $10 \mathrm{~m}$ depth ranged from 32.2 to $33.5 \mathrm{psu}$, while those were relatively higher at $50 \mathrm{~m}$ depth,ranging from 33.95 to $34.32 \mathrm{psu}$. Water salinities in fall ranged from 33.0 to $33.7 \mathrm{psu}$ at three-depth layers. Approximately, salinities at $200 \mathrm{~m}$ depth or at maximum depth of sampling stations were higher (>34.00 psu) than shallower water depths in all seasons.

A total of 215 species belonging to 65 families in eight phyla were identified. Total species number of zooplankton varied with season. Total species number was highest in summer (200 species), followed by fall ( 130 species) and spring ( 102 species), and lowest in winter (82 species). The seasonal pattern of mean density was reverse to total species number. Seasonal mean density of zooplankton was highest in fall (463.1 inds. $\left.\mathrm{m}^{-3}\right)$, followed by summer (287.6 inds. $\mathrm{m}^{-3}$ ) and spring $\left(240.5\right.$ inds. $\left.\mathrm{m}^{-3}\right)$, and was lowest in winter (165.2 inds. $\mathrm{m}^{-3}$ ) (Fig. 5).

Species richness was highest in summer (13.5), followed by fall (12.3) and spring (8.7), and lowest in winter (7.5). Diversity index was highest in summer (3.2), followed by fall (2.7) and spring (2.4), and lowest in winter (2.2). Evenness index was relatively higher in summer (0.7) than other seasons (0.6) (Fig. 6).

In addition, the zooplankton community were significantly different between seasons $(R>0.85, p=0.001)$. These average dissimilarities varied from $58.6 \%$ (spring vs fall) to $75.5 \%$ (winter vs summer) (Table 1). Moreover, the clustering and ordination (nMDS) analyses indicated that neighboring stations had relatively higher similarity induces than stations at farther distances (Fig. 7,8).

Marine zooplankton were constituted by diverse marine organisms (Mackas and Tsuda, 1999). Their diversity tend to have peaks in the subtropical and temperate regions of northern hemisphere such as the East Sea (Park and Choi, 1997; Kang et al., 2002; Rebstock and Kang, 2003; Ashjian et al., 2005; Rombouts et al., 2009).

The spatial distribution of zooplankton densities varied

Table 1: Summary of one-way ANOSIM and SIMPER analysis between seasons

\begin{tabular}{llll}
\hline Group & \multicolumn{2}{c}{ One-way ANOSIM } & \multirow{2}{*}{$\begin{array}{l}\text { SIMPER Average } \\
\text { dissimilarity (\%) }\end{array}$} \\
\cline { 2 - 3 } & R-value & p-value & \\
\hline Wintervs Spring & 0.981 & 0.001 & 67.00 \\
Wintervs Summer & 0.989 & 0.001 & 75.47 \\
Winter vs Fall & 0.995 & 0.001 & 69.74 \\
Spring vs Summer & 0.975 & 0.001 & 69.63 \\
Spring vs Fall & 0.881 & 0.001 & 58.63 \\
Summer vs Fall & 0.850 & 0.001 & 64.12 \\
\hline
\end{tabular}



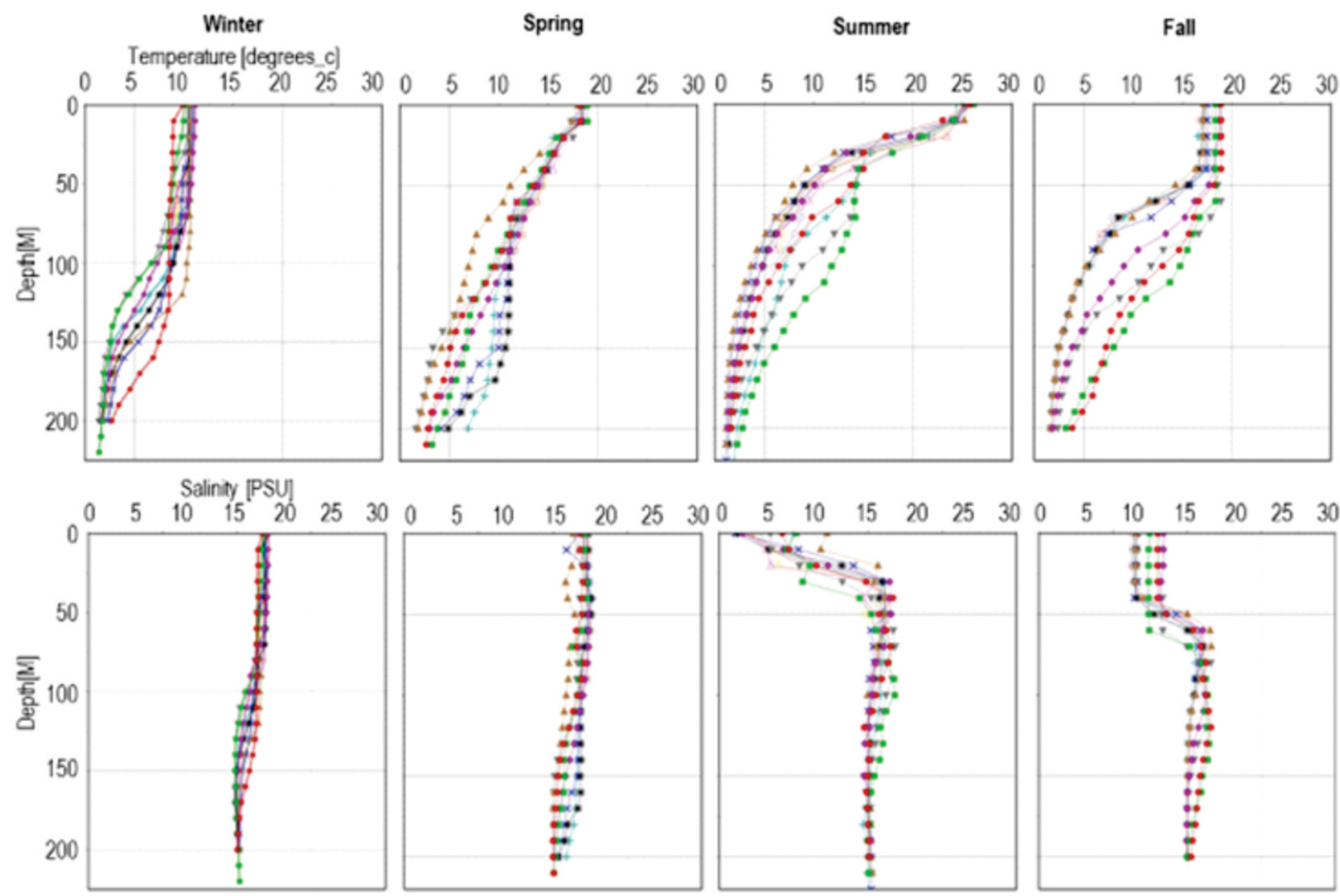

Fig. 2 : Seasonal vertical profile of temperature (upper) and salinity (bottom) around Dokdo in the East Sea. Colored lines and symbols indicate sampling.

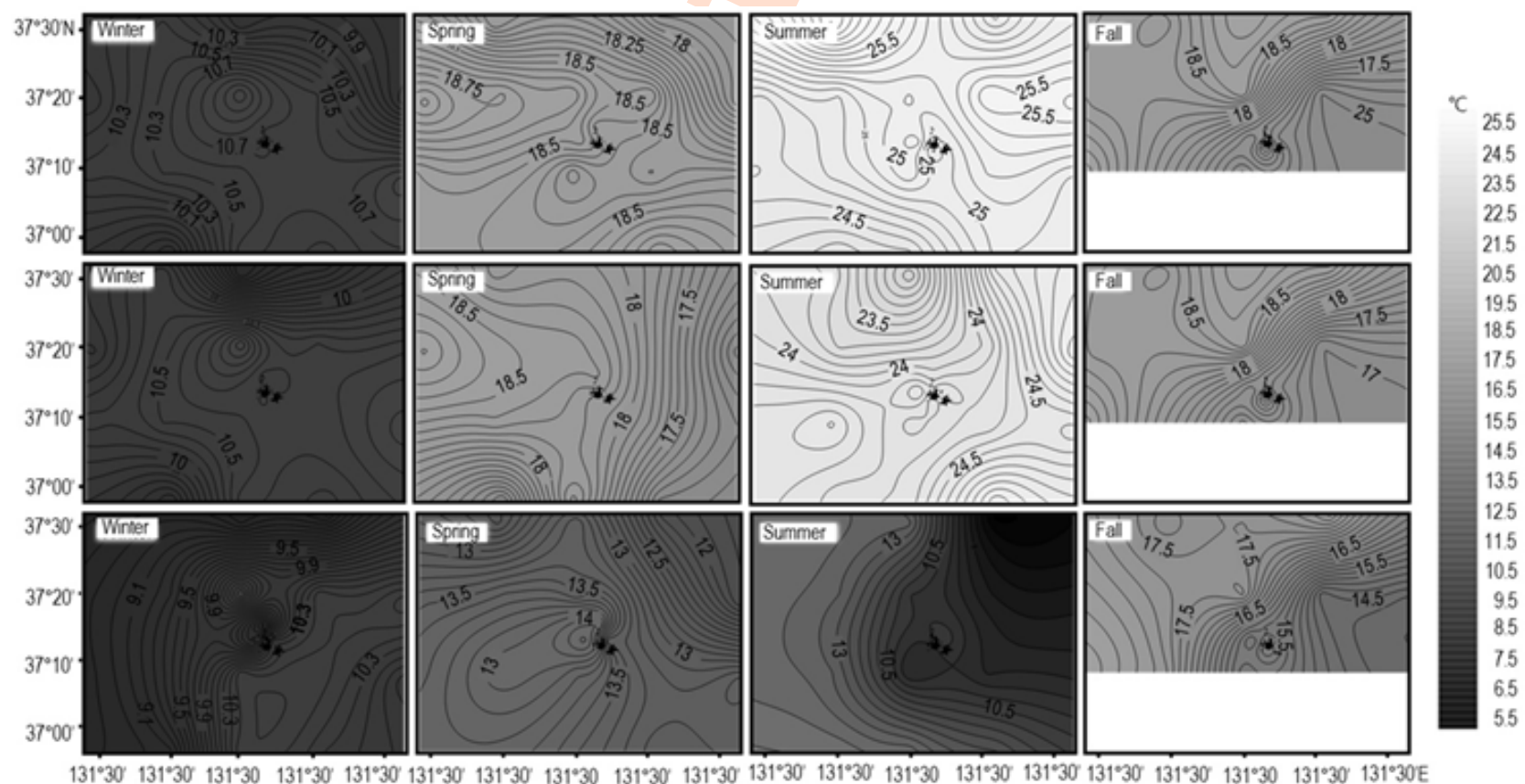

Fig. 3 : Seasonal horizontal distribution of temperature at $1 \mathrm{~m}$ depth (upper row), $10 \mathrm{~m}$ depth (middle row) and $50 \mathrm{~m}$ depth (bottom row) around Dokdo in the East Sea. 


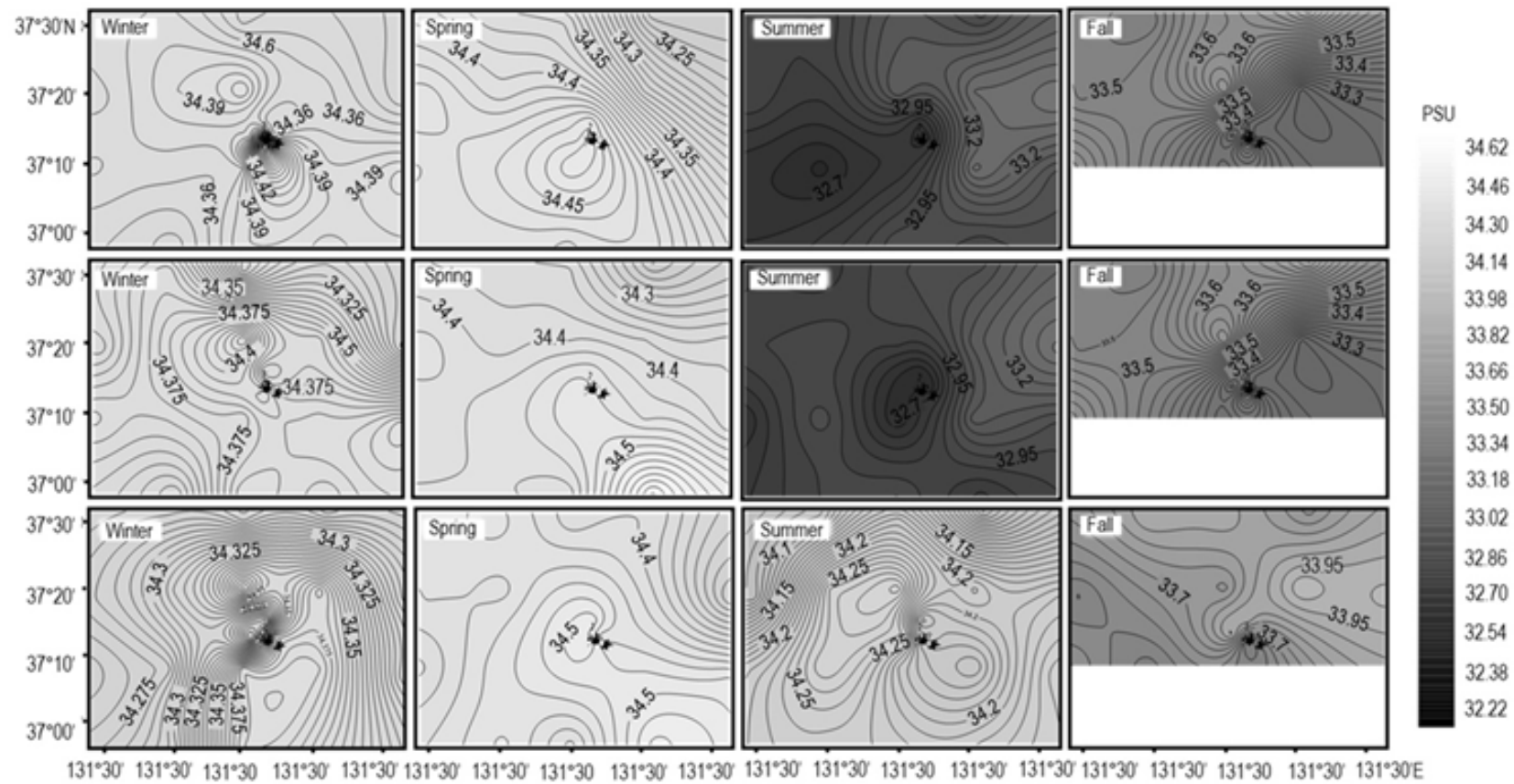

Fig. 4 : Seasonal horizontal distribution of salinity at $1 \mathrm{~m}$ depth (upper row), $10 \mathrm{~m}$ depth (middle row) and $50 \mathrm{~m}$ depth (bottom row) around Dokdo in the East Sea.

with stations and seasons (Fig. 9). The highest and lowest zooplankton densities mostly occurred at stations around Dokdo and on the northern part of Dokdo. During winters, the highest zooplankton density occurred at station B1 (316.3 inds. $\mathrm{m}^{-3}$ ) and the lowest at station DD4 (58.3 inds. $\left.\mathrm{m}^{-3}\right)$. During spring, zooplankton density was highest near Dokdo at station DD3 (430.1 inds. $\mathrm{m}^{-3}$ ) and lowest at station B3 (89.3 inds. $\mathrm{m}^{-3}$ ) in the northern stations of Dokdo Islets. During summers, zooplankton density was highest at station A3 (486.1 inds. $\mathrm{m}^{-3}$ ) and lowest at station B5 (93.8 inds. $\mathrm{m}^{-3}$ ) which were located in the north of Dokdo. Similar to zooplankton distribution pattern in spring, zooplankton density in fall was highest at station DD4 (801.5 inds. $\mathrm{m}^{-3}$ ) which was located near Dokdo and lowest at station B1 (56.5 inds. $\mathrm{m}^{-3}$ ).

Zooplankton are ectothermic marine organism with short generation time (Richardson, 2008; Rombouts et al., 2009). Any environmental change, either long- or short-term changes densities (Rombouts et al., 2009). The seasonal pattern of zooplankton densities is generally characterized by a peak in spring and low in winter (Hirota and Hasegawa, 1999; Chiba and Saino, 2003; Dolganova and Zuenko, 2004). However, in this study, high densities in fall corporates the previous studies (Kang et al., 2002; Kang et al., 2004; Walkusz et al., 2009; Jo et al., 2016).

Seasonal changes in zooplankton densities are probably influenced by warm and saltier waters from the East Korea Warm Current as a branch of Tsushima Warm Current (Iguchi, 2004).
Tsushima Warm Current flows northward to the East Sea, bringing warm and saline waters in fall and weakly in winter (Cho and Kim, 1996; Zhang et al., 2000; Ashjian et al., 2006). During fall, appearance of warm water is indicated by temperature lower than summer but higher than winter $\left(\sim 18^{\circ} \mathrm{C}\right)$, and salinities higher than summer but lower than winter and spring ( 33 psu). Zooplankton densities around Dokdo in the East Sea were high in warm-water and low in cold-water (Park and Choi, 1997). Park et al. (1998) reported that seasonal fluctuation of zooplankton densities was influenced by water temperature in the East Sea.

A total of 15 major taxa of zooplankton were dominated in the East Sea around Dokdo. Copepods were predominant during the entire seasons ranging from 46.9 to $75.4 \%$ of total zooplankton. The second dominant group of amphipods, except in summer, comprised $26.3 \%$ in spring. Other groups varied from 11.4 to $0.02 \%$ (Fig. 10). Six species contributed major proportions of zooplankton densities in winter and spring, nine species in summer and ten species in fall (Table 2), respectively.

In winter, copepods were the most dominant zooplankton group, constituting $56.4 \%$ of total zooplankton. The dominant copepod species were Metridia pacifica, Calanus sinicus and Mesocalanus tenuicornis, while the dominant non-copepods species were Themisto sp. juvenile, Conchoecia spp. and Atlanta spp. The mean densities of all dominant species ranged from 6.5 to 36.2 inds. $\mathrm{m}^{-3}$ and reached 4.0 to $24.8 \%$ of total zooplankton. In spring, copepods were dominant group, constituting $46.9 \%$ of total zooplankton. The dominant copepods species were Oithona 


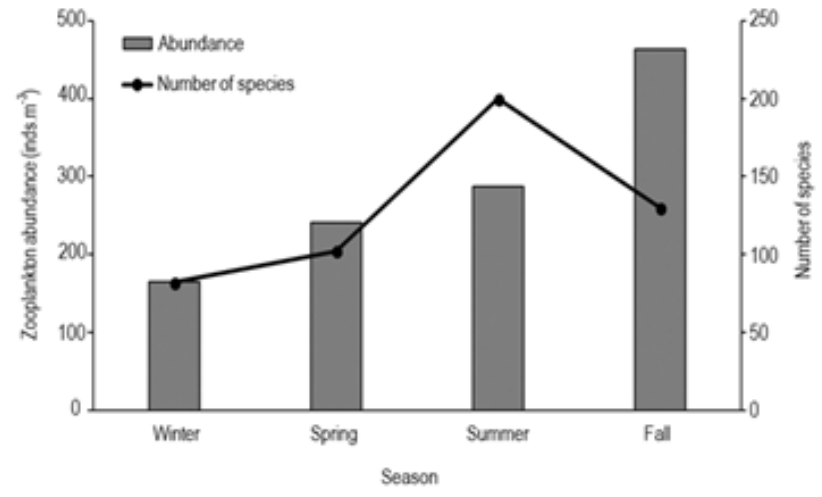

Fig. 5 : Mean density and number of species of zooplankton around Dokdo in the East Sea during the study period

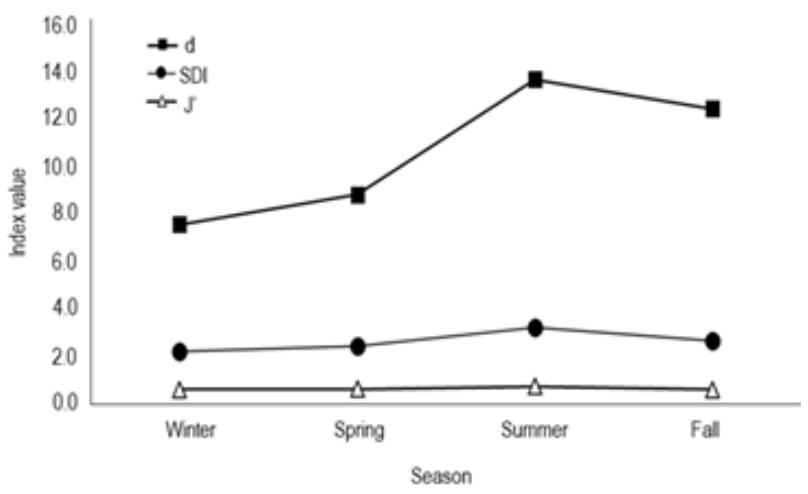

Fig. 6 : The diversity indices of zooplankton community around Dokdo in the East Sea during the study period $(\bullet)$ species richness; $(\bullet)$ diversity index; $(\Delta)$ evenness index.

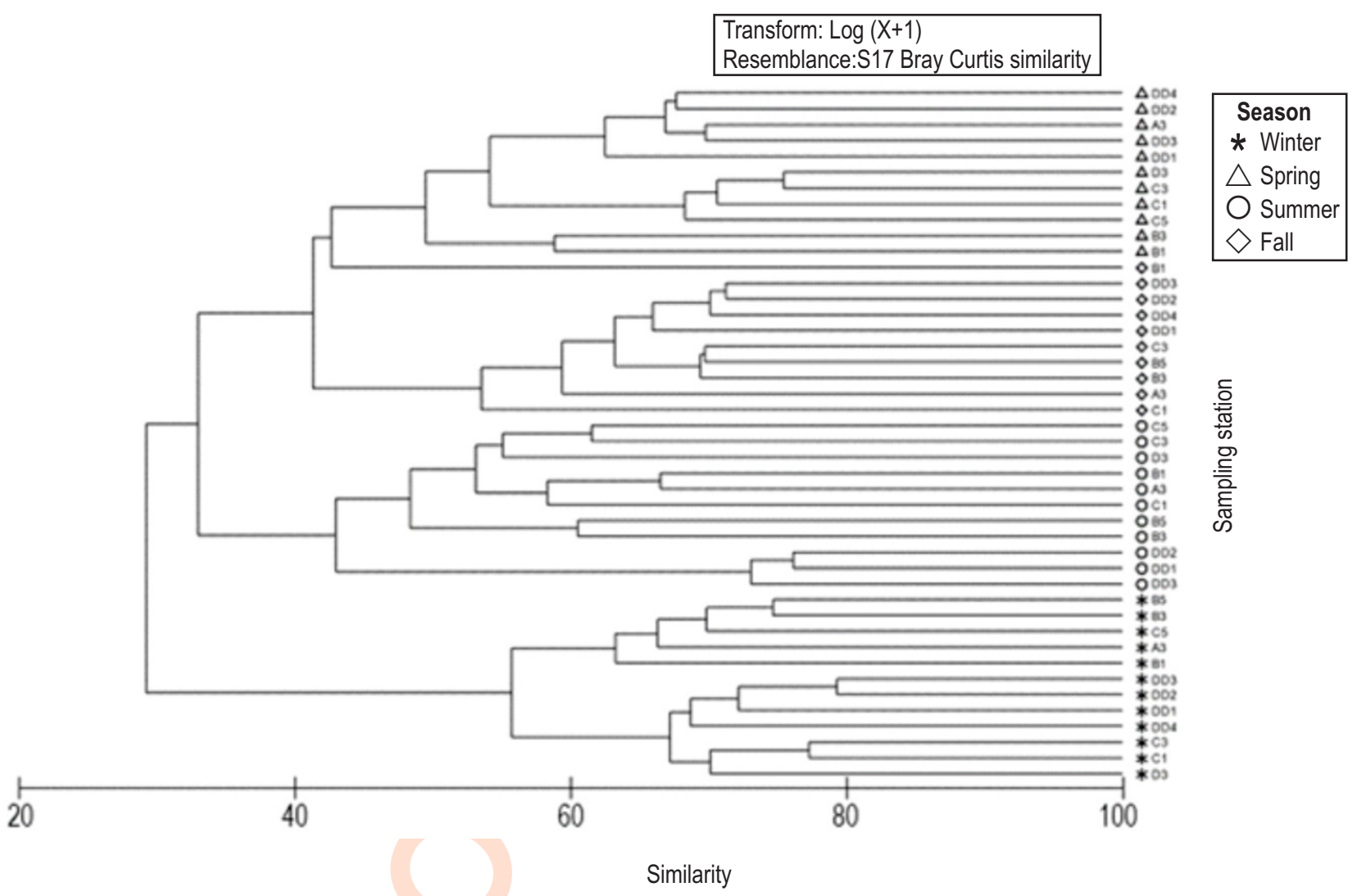

Fig. 7 : Cluster similarity of zooplankton between stations and seasons.

atlantica, Metridia sp. copepodite and C. sinicus. Amphipods as a second dominant group were dominated by Themisto sp. juvenile, while other dominant species were Oikopleura and calyptopis of euphausiids. The mean densities of dominant species ranged from 9.3 to 59.8 inds. $\mathrm{m}^{-3}$ and contributed 3.8 to $23.5 \%$ of total zooplankton. During summer, copepods were dominant, comprising $50.1 \%$ of total zooplankton. The dominant copepods species were Acartia pacifica, O. atlantica, C. sinicus, M. tenuicornis and Paracalanus parvus. In summer, amphipods were replaced by Doliolum spp. as the second dominant taxa. Other dominant species were zoeae of luciferid spp., Oikopleura and sagittid juvenile. The mean densities of these dominant 
species ranged from 10.5 to 31.3 inds. $\mathrm{m}^{-3}$ and 3.4 to $11.2 \%$ of total zooplankton.

In the present study, the most dominant zooplankton taxa around Dokdo in the East Sea was copepods, representing 47$75 \%$ of total zooplankton and 50 to $>80 \%$ in previous studies (Hirakawa et al., 1995; Kang et al., 2002; Rebstock and Kang, 2003). Other dominant taxa were amphipods and doliolids (Park et al., 1998; Chiba and Saino, 2003). They prevailed as secondary dominant groups in the temperate sea with a high percentage, being comprised $>11 \%$, particularly in the East Sea around Dokdo (Berner and Reid, 1961; Ikeda, 1990; Park et al., 2016a).

In fall, similar to other seasons, copepods were out numbered, charging $75.4 \%$ of total zooplankton the dominant species from this group were Paracalanus parvus, Oncaea venusta, Paracalanus aculeatus, C. sinicus, Euchaetid spp. copepodite, 0 . atlantica and calanoid copepodites. Themisto sp. juvenile was a subdominant specie, followed by Conchoecia spp. and Doliolum spp. The mean densities of these dominant species ranged from 17.0 to 100.4 inds. $\mathrm{m}^{-3}$ and 3.5 to $14.3 \%$ of total zooplankton.
Fluctuation in water temperature influences not only zooplankton densities but also species number. Increase or decrease of species number is contributed by temperature changes (Park et al., 1998). Change in species number is significantly correlated with water temperature (Park et al., 2016a). Temperature change results in the possibility of cooccurrence of warm and cold water species, further increasing the number of zooplankton species, particularly in summer (Park and Choi, 1997). As Dokdo is located in the temperate waters, zooplankton composition mostly consist of temperate species, which prefer warm-water condition (Park et al., 2016a). Also, immigrating warm-adapted species can increase species number in zooplankton community (Beaugrand et al., 2010).

Rising sea surface temperatures provoke changes in zooplankton community composition towards warm-water species (Lewandowska et al., 2014). During warm-water condition above $15^{\circ} \mathrm{C}$ (Park et al., 1998), warm-adapted species such as small size copepods (Oithona atlantica, Acartia pacifica, Oncaea venusta, and Paracalanus parvus) (Morgan et al., 2003; Turner, 2004; Ashijan et al., 2005; Kang, 2011) and gelatinous zooplankton (Doliolum sp.) are dominant (Berner and Reid, 1961; Richardson, 2008; Park et al., 2016b). These species occur

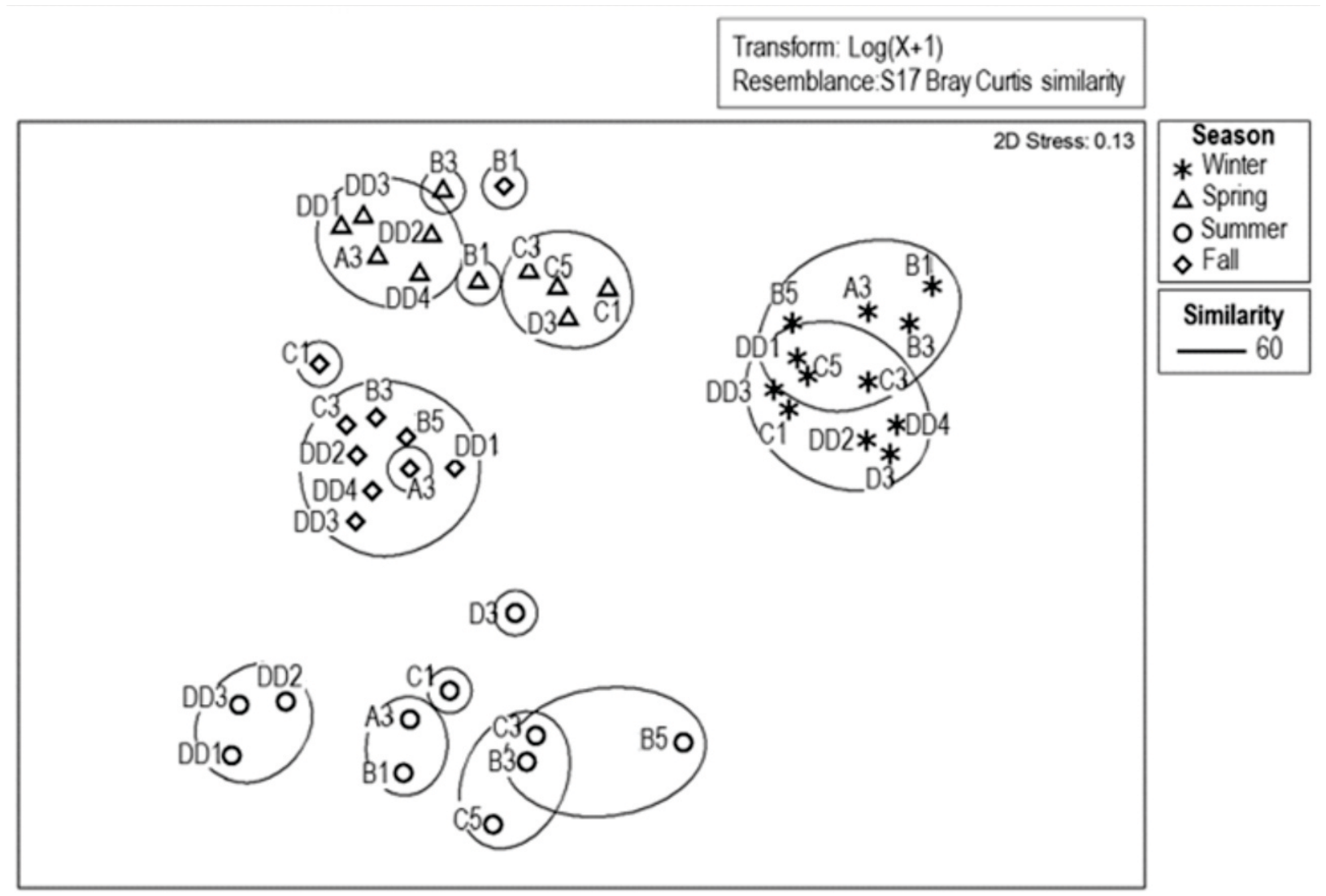

Fig. 8 : Non-metric multidimensional scaling (nMDS) of zooplankton between stations and seasons. 


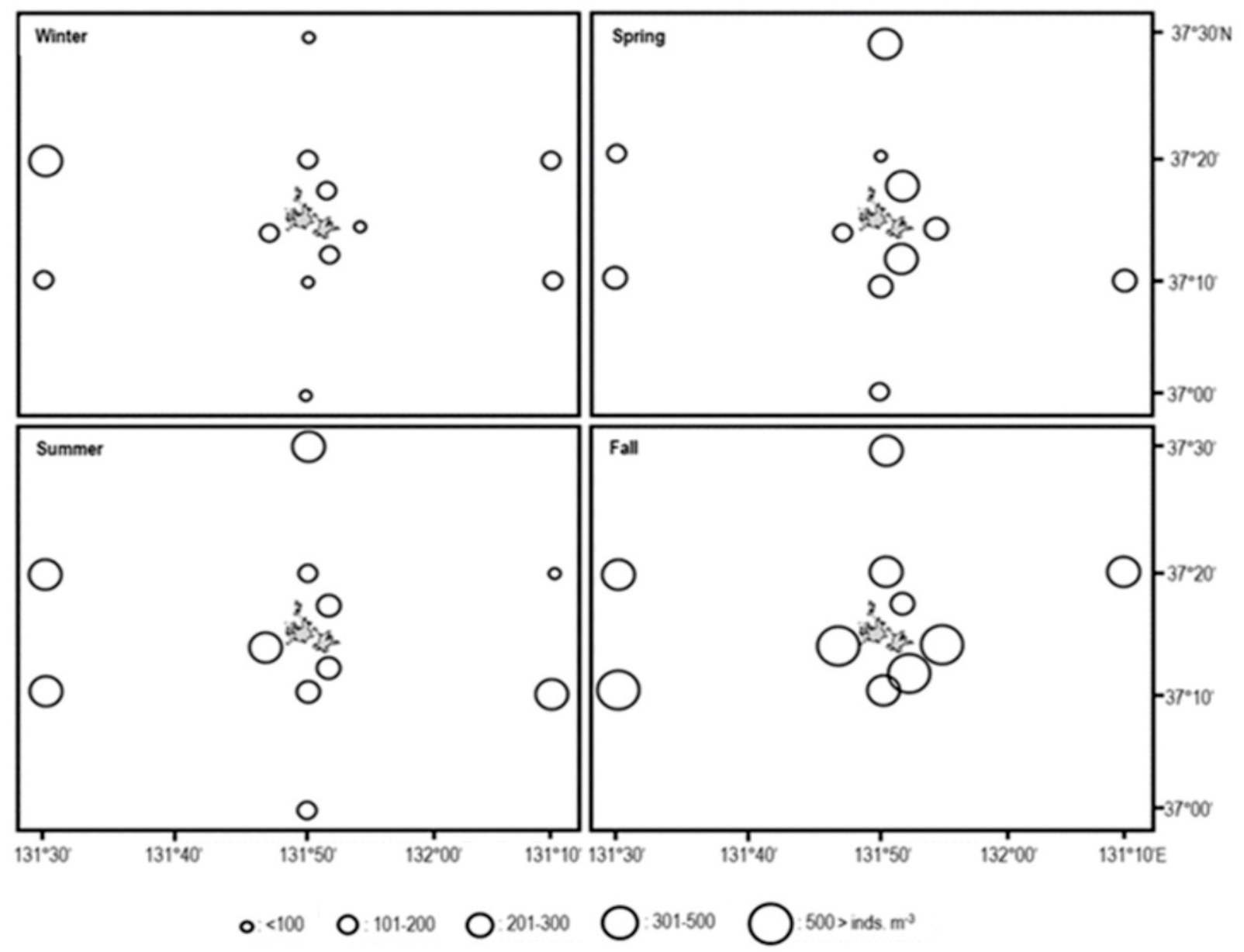

Fig. 9 : Seasonal spatial distribution of zooplankton densities in the East Sea.

mainly during spring, summer and fall at shoal and warm water areas nearby Dokdo. Further, juvenile of Themisto sp. were found at the shallow layer near Dokdo, while adults are present in colder water at deep layer offshore (Nishimura, 1965; lkeda, 1990).

On the other hand, decreasing seawater temperature also has an effect on zooplankton composition distribution. During winters, zooplankton community is dominated by some large sized species, such as Metridia spp., Themisto spp. and euphausiids (Gislason and Silva, 2012; Chiba et al., 2015). Metridia spp. are well known as a dominant species in the northern hemisphere, particularly $M$. pacifica in the East Sea/Japan Sea (Morioka et al., 1977; Hirakawa et al., 1992; Park et al., 2016b). These predominant species are greatly abundant at the stations off Dokdo, approximately $200 \mathrm{~m}$ depth and temperature less than $5^{\circ} \mathrm{C}$ in winter (Mackas and Tsuda, 1999).
This species has been known to prefer cold-water condition of temperature lower than $9^{\circ} \mathrm{C}$ and as an indicator species of cold water in the East Sea (Morioka et al., 1977; Hirakawa et al., 1992; Park et al., 2016a). While, as water temperature reduces, warmwater zooplankton such as Doliolum spp.and $A$. pacifica begin to disappear, however, Themisto sp. and O. atlantica may survive till the next season (Nishimura, 1965; Kang, 2011).

Seasonal appearance of dominant taxa : The dominant species in all seasons were represented by large sized species (Themisto sp. juvenile and Metridia pacifica), small sized copepods (Oithona atlantica, Oncaea venusta, Acartia pacifica and Paracalanus parvus)and gelatinous zooplankton (Doliolum spp.) (Fig. 11). Themisto sp. juvenile and $O$. atlantica seasonally fluctuated with high mean density in spring. The density of $M$. pacifica was higher than other species in winter, while that of 0 . 

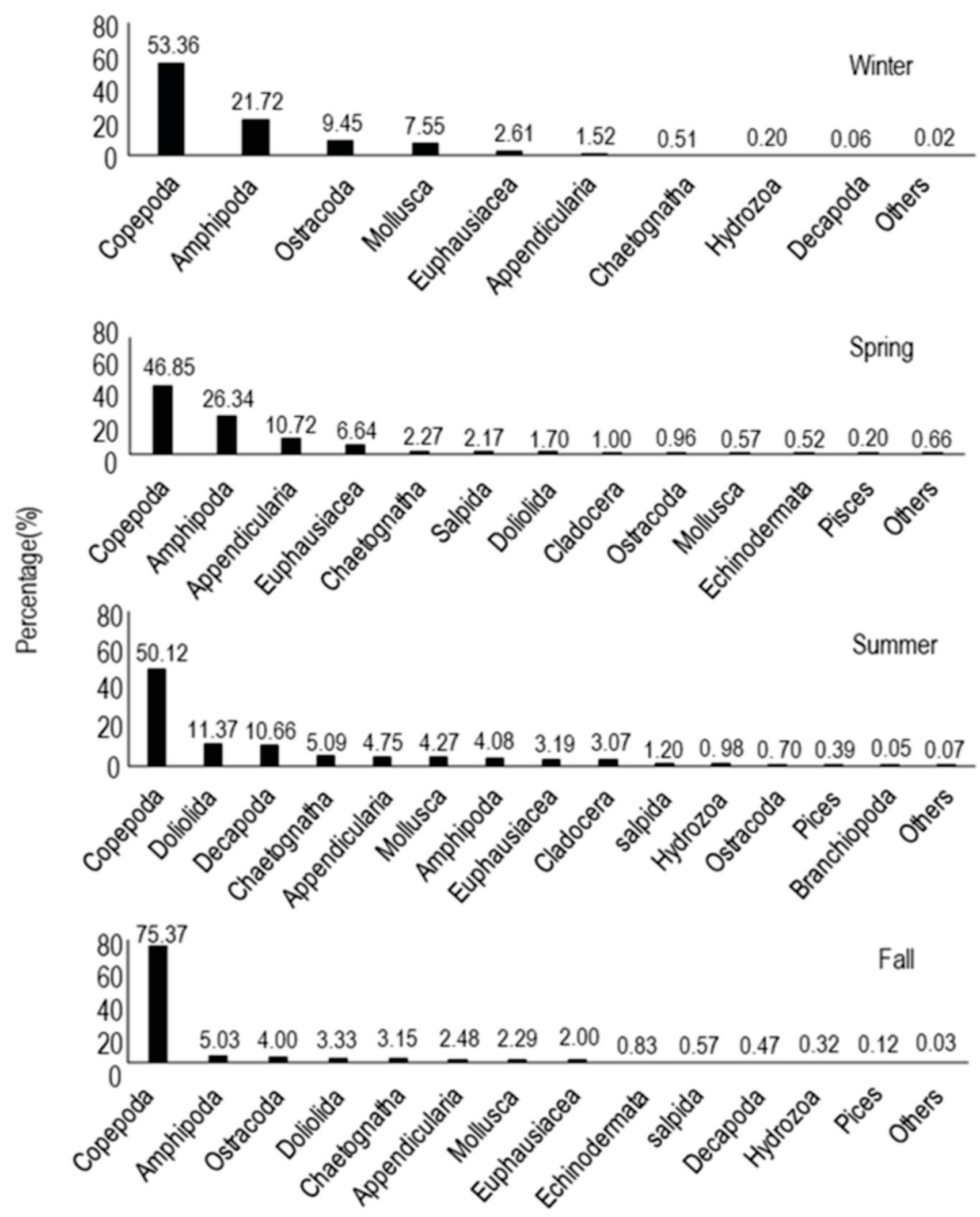

Fig. 10 : Seasonal changes of relative proportion of dominant zooplankton groups around Dokdo in the East Sea. 


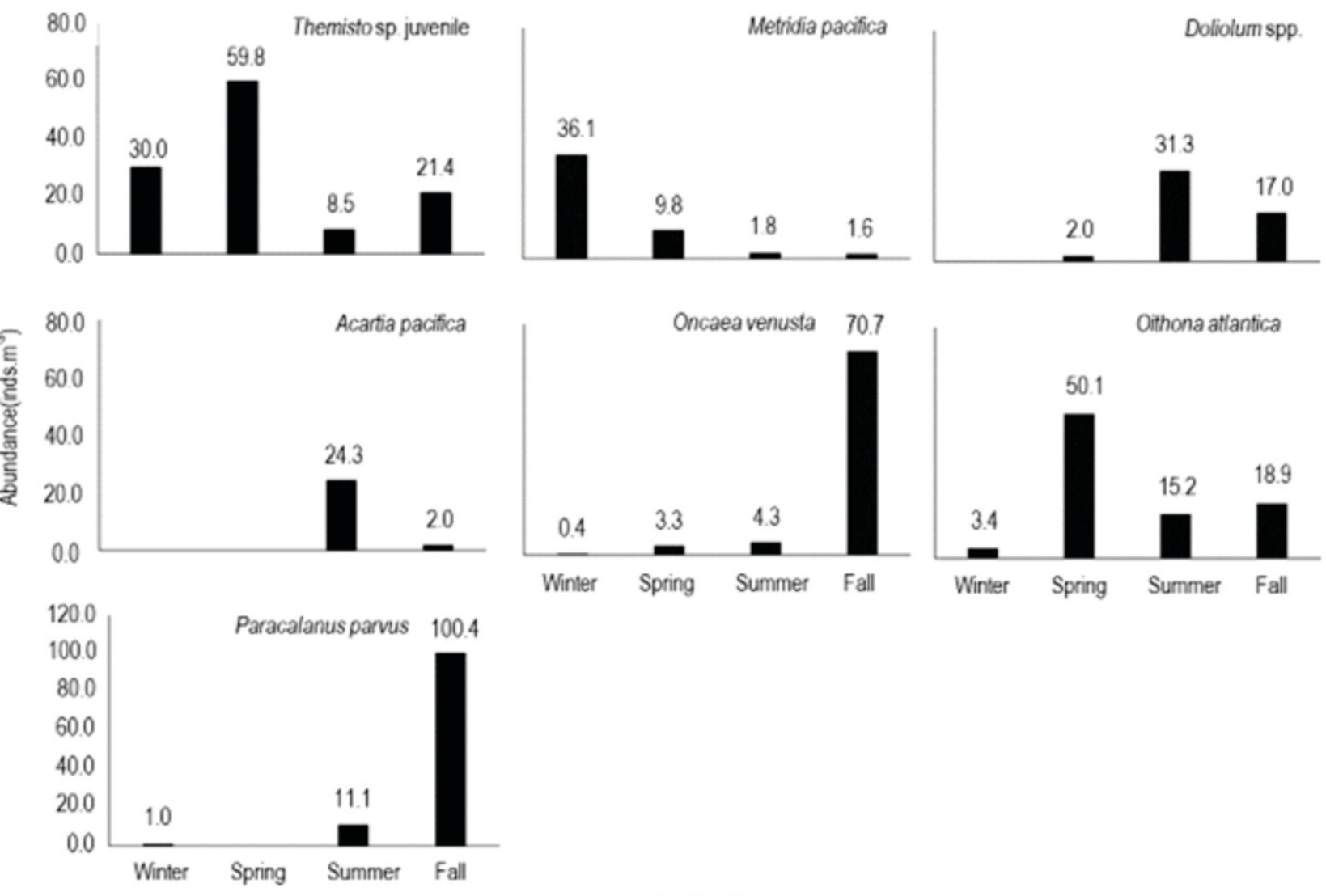

Fig. 11 : Seasonal variations of appearance dominant species around Dokdo in the East Sea.

Table 2 : Seasonal dominant species in contributing zooplankton densities around Dokdo in the East sea

\begin{tabular}{|c|c|c|c|c|c|}
\hline Species & $\begin{array}{l}\text { Mean density } \\
\text { (inds. } \mathrm{m}^{-3} \text { ) }\end{array}$ & $\begin{array}{l}\text { Percentage of } \\
\text { contribution(\%) }\end{array}$ & Species & $\begin{array}{l}\text { Mean density } \\
\left(\text { inds. } \mathrm{m}^{-3} \text { ) }\right.\end{array}$ & $\begin{array}{l}\text { Percentage of } \\
\text { contribution(\%) }\end{array}$ \\
\hline Winter & & & Spring & & \\
\hline Metridia pacifica & 36.2 & 24.8 & Themisto sp. juvenile & 59.8 & 23.5 \\
\hline Themisto sp. juvenile & 30.0 & 20.1 & Oithona atlantica & 50.1 & 19.5 \\
\hline Calanus sinicus & 15.2 & 9.9 & Oikopleura spp. & 25.8 & 9.0 \\
\hline Conchoecia spp. & 18.4 & 9.9 & Euphausiid calyptopis & 13.9 & 5.7 \\
\hline Atlanta spp. & 11.0 & 7.4 & Metridia sp. copepodite & 21.5 & 5.0 \\
\hline Mesocalanus tenuicornis & 6.5 & 4.0 & Calanus sinicus & 9.3 & 3.8 \\
\hline Fall & & & Summer & & \\
\hline Paracalanus parvus & 100.4 & 14.3 & Doliolum spp. & 31.3 & 11.2 \\
\hline Oncaea venusta & 70.7 & 14.8 & Acartia pacifica & 24.3 & 7.4 \\
\hline Paracalanus aculeatus & 58.4 & 14.3 & Oithona atlantica & 15.2 & 4.8 \\
\hline Calanus sinicus & 38.8 & 7.4 & Calanus sinicus & 15.1 & 5.3 \\
\hline Euchaetid spp. copepodite & 27.0 & 5.9 & Luciferid spp. zoea & 15.1 & 4.4 \\
\hline Themisto sp. juvenile & 21.4 & 5.0 & Mesocalanus tenuicornis & 18.8 & 5.1 \\
\hline Oithona atlantica & 18.9 & 4.6 & Oikopleura spp. & 13.7 & 4.6 \\
\hline Calanoid spp. copepodite & 21.0 & 3.8 & Paracalanus parvus & 11.1 & 3.8 \\
\hline Conchoeciaspp. & 18.5 & 4.4 & Sagittid spp. juvenile & 10.5 & 3.4 \\
\hline Doliolum spp. & 17.0 & 3.5 & & & \\
\hline
\end{tabular}


venusta was higher in fall. The occurrence pattern of $A$. pacifica, Doliolum spp. and $P$. parvus varied seasonally. A. pacifica did not occur in winter and spring, however was found in peak during summer. Similarly, Doliolum spp. not only appeared in winter, however, dominated in summer. P. parvus was absent in spring, but dominant in fall.

This study clearly indicates seasonal changes in diversity, composition, distribution of zooplankton community from the domination of cold-water species (e.g. M. pacifica) in winter to warm-water species (A. pacifica, O. venusta and Themisto sp.) and gelatinous zooplankton species (Doliolum spp.) in spring through fall. High species number, densities and dominant species in warm-water conditions explain that water temperature has a positive correlation with zooplankton community composition and distribution (Park et al., 1998; Han et al., 1995). However, variance in salinities (32-34 psu) was not related with the abundance and distribution of zooplankton community directly because all these species, particularly the dominant species were neritic and oceanic species, which inhabited saline water having salinity > 30 psu (Park et al., 1997; Park et al., 2016a). Our results corroborates with the previous records on zooplankton communities (Park et al., 1997, 1998, Han et al. 1995). Thus, from this study it can be concluded that the seasonal trends of hydropgraphies in the East Sea/Japan Sea controlled zooplankton community abundance, composition and distribution. These trends were regulated by water masses, temperature and salinity.

\section{Acknowledgment}

This work was supported by a grant received from the National Institute of Fisheries Science (R2019023).

\section{References}

Ashjian, C.J., R. Arnone, C. Davis, B. Jones, M. Kahru, C. Lee and B.G. Mitchell: Biological structure and seasonality in the Japan/East Sea. Oceanograp., 19, 122-133 (2006).

Ashjian, C.J., C.S. Davis, S.M. Gallager and P. Alatalo: Characterization of the zooplankton community, size composition and distribution in relation to hydrography in the Japan/East Sea. Deep-Sea Res., II,52,1363-1392 (2005).

Beaugrand, G., M. Edwards and L. Legendre: Marine biodiversity, ecosystem functioning, and carbon cycles. Proc. Natl. Acad. Sci. USA, 107, 10120-10124 (2010).

Berner, L.D., J.L. Reid Jr.: On the response to changing temperature of the temperature-limited plankter Doliolum denticulatum Quoy and Gaimard 1835. Limnol. Oceanogr., 6, 205-215(1961).

Chang, K.I., Y.B. Kim, M.S. Suk and S.K. Byun: Hydrography around Dokdo. Ocean Polar Res., 24, 369-389 (2002).

Chang, K.I., W.J. Teague, S.J. Lyu, H.T. Perkins, D.K. Lee, D.R. Watts, Y.B. Kim, D.A. Mitchell, C.M. Lee and C.K. Lee: Circulation and currents in the southwestern East/Japan Sea: Overview and review. Prog. Oceanogr., 61, 105-156 (2004).

Chiba, S. and T. Saino: Variation in mesozooplankton community structure in the Japan/East Sea (1991-1999) with possible influence of the ENSO scale climatic variability. Prog. Oceanogr., 57, 317-339 (2003).

Chiba, S., S.D. Batten, T. Yoshiki, Y. Sasaki, K. Sasako, H. Sugisaki and T. Ichikawa: Temperature and zooplankton size structure: Climate control and basin-scale comparison in the North Pacific. Ecol. Evol., 5, 968-978(2015).

Cho, Y.K. and K. Kim: Seasonal variation of the East Korea Warm Current and its relation with the colder water. La mer., 34, 172-182 (1996).

Chough, S.K., H.J. Lee and S.H. Yoon: Marine geology of Korean Seas. $2^{\text {nd }} \mathrm{Edn}$., Elsevier, Amsterdam (2000).

Clarke, K.R.: Non-parametric multivariate analyses of changes in community structure. Aust. J. Ecol., 18, 117-143(1993)

Clarke, K.R. and R.M. Warwick: Change in marine communities: An approach to statistical analysis and interpretation, $2^{\text {nd }} E d n$. PrimerELtd., Plymouth, UK., pp. 1-4 (2001).

Dolganova, N.T. and Y.I. Zuenko: Seasonal and inter-annual dynamics of mesoplankton in the northwestern Japan Sea. Prog. Oceanogr., 61, 227-243 (2004).

Field, J.G., K.R. Clarke and R.M. Warwick: A practical strategy for analysing multispecies distribution patterns. Mar. Ecol. Prog. Ser., 8, 37-52 (1982).

Gislason, A. and T. Silva: Abundance, composition, and development zooplankton in the Subarctic Iceland Sea in 2006, 2007 and 2008. ICES J. Mar. Sci., 69, 1263-1276 (2012).

Han, D.H., S.Y. Hong and C.W. Ma: Distribution of zooplankton in Deukryang Bay, Korea. J. Korean. Fish. Soc., 28, 517-532 (1995).

Hillebrand, H., T. Burgmer and E. Biermann: Running to stand still: Temperature effects on species richness, species turnover, and functional community dynamics. Mar. Biol., 159, 2415-2422 (2012).

Hirakawa, K., A. Imamura and T. Ikeda: Seasonal variability in abundance and composition of zooplankton in Toyama Bay, Southern Japan Sea. Bull. Japan Sea Nat. Fish. Res. Inst., 42, 115(1992).

Hirakawa, K., M. Kawan, S. Nishihama and S. Ueno: Seasonal variability in abundance and composition of zooplankton in the vicinity of the Tsushima Straits, southwestern Japan Sea. Bull. Japan Sea Nat. Fish. Res. Inst., 45, 25-38 (1995).

Hirota, Y. and S. Hasegawa: The zooplankton biomass in the Sea of Japan. Fish. Oceanogr., 8, 274-283 (1999)

Iguchi, N.: Spatial/temporal variations in zooplankton biomass and ecological characteristics of major species in the southern part of Japan Sea: Areview. Prog. Oceanogr., 61, 213-225 (2004).

Ikeda, T.: A growth model for a hyperiid amphipod Themisto japonica (Bovallius) in the Japan Sea, based on it intermoult period and moult increment. J. Oceanogr. Soc. Japan., 46, 261-272 (1990).

Jo, N., J.J. Kang, W.G. Park, B.R. Lee, M.S. Yun, J.H. Lee, S.M. Kim, D. Lee, H.T. Joo, J.H. Lee, S.H. Ahn and S.H. Lee: Seasonal variation in the biochemical compositions of phytoplankton and zooplankton communities in the southwestern East/Japan Sea. Deep-Sea Res. II, 143, 82-90(2016).

Johnson, W.S. and D.M. Allen: Zooplankton of the Atlantic and Gulf Coasts: A guide to their identification and ecology. Johns Hopkins University Press, Baltimore (2012).

Kang, J.H.: The occurrence of Acartia species and their environmental characteristics at three ports in Korea. Ocean Sci. J., 46, 219-237 (2011).

Kang, J.H., W.S. Kim and J.H. Shim: Species composition and 
abundance of zooplankton community in spring and autumn around Dokdo. Ocean Polar Res., 24, 407-417 (2002).

Kang, J.H., W.S. Kim, K.I. Chang and J.H. Noh: Distribution of plankton related to the mesoscale physical structure within the surface mixed layer in the southwestern East Sea, Korea. J. Plankton Res., 26, 1515-1528 (2004).

Kim, K., K.R. Kim, Y.G. Kim, Y.K. Cho, D.J. Kang, M. Takematsu and Y. Volkov: Water masses and decadal variability in the East Sea (Sea of Japan). Prog. Oceanogr., 61, 157-174 (2004).

Kim, K.R., S.H. Lee, K.A. Park, J.J. Park, Y.S. Suh, D.K. Lee and K.I. Chang: General Introduction. In: Oceanography of the East Sea (Japan Sea) (Eds.: K.I. Chang, C.I. Zhang, C. Park, D.J. Kang, S.J. Ju, S.H. Lee, M. Wimbush). Springer, Switzerland, pp.1-31 (2016).

Krause, M., J.W. Dippner and J. Beil: A review of hydrographic controls on the distribution of zooplankton biomass and species in the North Sea with particular reference to a survey conducted in January-March 1987. Prog. Oceanogr., 35, 81-152 (1995).

Lance, J.: The salinity tolerance of some estuarine planktonic copepods. Limnol. Oceanogr., 8, 440-449 (1963).

Lance, J.: The salinity tolerances of some estuarine planktonic crustaceans. Biol. Bull., 127, 108-118 (1964).

Legendre, P. and L. Legendre: Numerical Ecology. $2^{\text {nd }}$ Edn., Elsevier, Amsterdam, pp. 40-43 (1998).

Lewandowska, A.M., H. Hillebrand, K. Lengfellner and U. Sommer: Temperature effects on phytoplankton diversity-The zooplankton link. J. Sea Res., 85, 359-364 (2014).

Mackas, D.L. and A. Tsuda: Mesozooplankton in the eastern and western subarctic Pacific: community structure, seasonal life histories, and interannual variability. Prog. Oceanogr., 43, 335-363 (1999).

Mauchline, J.: Advances in marine biology: The biology of Calanoid Copepods. Vol. 33, Academic Press, San Diego (1998).

Morgan, C.A., W.T. Peterson and R.L. Emmett: Onshore-offshore variations in copepod community structure off the Oregon coast during the summer upwelling season. Mar. Ecol. Prog. Ser., 249, 223-236 (2003).

Morioka, Y., M. Nagahara and Y. Komaki: Calanoid copepods as indicators of the cold watermass in the Japan Sea. Bull. Japan Sea. Reg. Fish. Res. Lab., 28, 51-58 (1977).

Nishimura, S.: The zoogeographical aspect of the Japan Sea, Part II. Publ. Seto. Mar. Biol. Lab., 13, 81-101 (1965).

Park, C. and J.K. Choi: Zooplankton community in the front zone of the East Sea of Korea (the Sea of Japan): 1. Species list, distribution of dominant taxa and species association. J. Korean Fish. Soc.,32.2, 225-238 (1997).

Park, C., C.R. Lee and S.Y. Hong: Patterns of vertical distribution and diel vertical migration of zooplankton in the East Sea of Korea (Sea of Japan). J. Korean Soc. Oceanogr., 32, 38-45 (1997).

Park, C., C.R. Lee and J.C. Kim: Zooplankton community in the front zone of the East Sea (the Sea of Japan), Korea: 2. Relationship between abundance distribution and seawater temperature. $J$. Korean Fish. Soc., 31, 749-759 (1998).

Park, J.J., K.A. Park, Y.G. Kim and J.Y. Yun: Water masses and their longterm variability. In: Oceanography of the East Sea (Japan Sea) (Eds.: K.I. Chang, C.I. Zhang, C. Park, D.J. Kang, S.J Ju, S.H. Lee and M. Wimbush). Springer, Switzerland, pp. 59-86 (2016a).

Park, C., H.L. Suh, Y.S. Kang, S.J. Ju and E.J. Yang: Zooplankton. In: Oceanography of the East Sea (Japan Sea) (Eds.: K.I. Chang, C.I. Zhang, C. Park, D.J. Kang, S.J Ju, S.H. Lee and M. Wimbush). Springer, Switzerland, pp. 297-326 (2016b).

Park, J.S., S.S. Lee, Y.S. Kang and S.H. Huh: Distribution of indicator species of copepods and chaetognaths in the middle East Sea of Korea and their relationships to the characteristics of water masses. Bull. Korean Fish. Soc., 24, 203-212 (1991).

Pepin, P., E. Colbourne and G. Maillet: Seasonal pattern in zooplankton community structure on the Newfoundland and Labrador Shelf. Prog. Oceanogr., 91, 273-285 (2011).

Pinca, S. and S. Dallot: Zooplankton community structure in the Western Mediterranean Sea related to mesoscale hydrodynamics. Hydrobiologia, 356, 127-142 (1997).

Rebstock, G.A. and Y.S. Kang: A comparison of three marine ecosystems surrounding the Korean peninsula: Responses to climate change. Prog. Oceanogr., 59, 357-379 (2003).

Richardson, A.J.: In hot water: Zooplankton and climate changes. ICES J. Mar. Sci., 65, 279-295 (2008).

Rochet, M. and E.H. Grainger: Community structure of zooplankton in eastern Hudson Bay. Can. J. Zool., 66, 1626-1630 (1988).

Rombouts, I., G. Beaugrand, F. Ibaňez, S. Gasparini, S. Chiba and L. Legendre: Global latitudinal variations in marine copepod diversity and environmental factors. Proc. R. Soc. B., 276, 3053-3062 (2009).

Talley, L.D., D.H. Min, V.B. Lobanov, V.A. Luchin, L.V. Ponomarev, A.N. Salyuk, A.Y. Shcherbina, P.Y. Tishchenko and I. Zhabin: Japan/East Sea water masses and their relation to the sea's circulation. Oceanography, 19.3,32-49 (2006).

Turner, J.T.: The importance of small planktonic copepods and their roles in pelagic marine food webs. Zool. Stud., 43, 255-266 (2004).

Varadharajan, D. and P. Soundarapandian: Distribution and abundance of zooplankton along Tamil Nadu Coastal Waters, India. J. Ecosys. Ecograph., 3, 135-139 (2013).

Walkusz, W., S. Kwasniewski, S. Falk-Petersen, H. Hop and V. Tverberg: Seasonal and spatial changes in the zooplankton community of Kongsfjorden, Svalbard. Polar Res., 28, 254-281 (2009).

Zhang, C.I., J.I. Lee, S. Kim and J.H. Oh: Climatic regime shifts and their impacts on marine ecosystem and fisheries resources in Korean waters. Prog. Oceanogr., 47, 171-190 (2000). 